\title{
Nonhost Resistance of Barley Is Successfully Manifested Against Magnaporthe grisea and a Closely Related Pennisetum-Infecting Lineage but Is Overcome by Magnaporthe oryzae
}

\author{
Nina Zellerhoff, ${ }^{1}$ Birgit Jarosch, ${ }^{1}$ Johannes Z. Groenewald, ${ }^{2}$ Pedro W. Crous, ${ }^{2}$ and Ulrich Schaffrath ${ }^{1}$ \\ ${ }^{1}$ Department of Plant Physiology, RWTH Aachen University, 52056 Aachen, Germany; ${ }^{2}$ Centraalbureau voor \\ Schimmelcultures, Fungal Biodiversity Center, 3584 CT Utrecht, The Netherlands
}

Submitted 25 November 2005. Accepted 8 May 2006.

\begin{abstract}
Magnaporthe oryzae is a major pathogen of rice (Oryza sativa L.) but is also able to infect other grasses, including barley (Hordeum vulgare L.). Here, we report a study using Magnaporthe isolates collected from other host plant species to evaluate their capacity to infect barley. A nonhost type of resistance was detected in barley against isolates derived from genera Pennisetum (fontaingrass) or Digitaria (crabgrass), but no resistance occurred in response to isolates from rice, genus Eleusine (goosegrass), wheat (Triticum aestivum L.), or maize (Zea mays L.), respectively. Restriction of pathogen growth in the nonhost interaction was investigated microscopically and compared with compatible interactions. Real-time polymerase chain reaction was used to quantify fungal biomass in both types of interaction. The phylogenetic relationship among the Magnaporthe isolates used in this study was investigated by inferring gene trees for fragments of three genes, actin, calmodulin, and $\beta$ tubulin. Based on phylogenetic analysis, we could distinguish different species that were strictly correlated with the ability of the isolates to infect barley. We demonstrated that investigating specific host interaction phenotypes for a range of pathogen isolates can accurately highlight genetic diversity within a pathogen population.
\end{abstract}

Additional keywords: hypersensitive response, $M L O$, papilla, qPCR, rice blast.

Plants, surrounded by a vast array of potentially pathogenic microorganisms, have become hosts only for a very limited number of pathogens. Resistance towards pathogens for which the plant species in question is not considered a host is termed nonhost resistance (Heath 2001). For example, a pathogen of peas would not necessarily be expected to infect other plants, e.g., potatoes, to which it has not had the opportunity to adapt in the course of evolution. Because of its durability, nonhost resistance is regarded as a robust protection against pathogenic invaders, and it was, therefore, often suggested that the mechanisms of nonhost resistance could be exploited to improve the resistance of crop plants (Thordal-Christensen 2003).

Holub and Cooper (2004) discriminated two types of nonhost resistance. The first is constitutive or passive and applies when the pathogen lacks the necessary pathogenicity factors. This is

Corresponding author: U. Schaffrath; Telephone: +49-241 8020100; Fax: +49-241 8022181; E-mail: schaffrath@bio3.rwth-aachen.de also termed nonspecific defense (Heath 2000). The second type of nonhost resistance has been described as inaccessibility, for example, when a preformed antimicrobial substance cannot be overcome by the pathogen or when inducible, active defenses keep the pathogen in check. The inability of the pathogen to suppress active plant defense would also be included in this category. Thus, nonhost resistance could be viewed not only as a host property but also as an inadequacy in the pathogen in terms of limited host specificity (Heath 2001). While nonhost resistance is generally thought to be a multigenically controlled trait in the plant (Mysore and Ryu 2004), the involvement of single dominant resistance genes has sometimes been demonstrated. For example, this may be the case for nonhost pathogen species having close relatives that are successful pathogens on that host (Heath 2001), e.g., some powdery mildews (Matsumura and Tosa 1995).

Magnaporthe isolates cause disease in several species from the family Poaceae. While it was recently reported that fungal isolates infecting rice and weed grasses associated with rice cultivation are of common origin (Couch et al. 2005), it was also demonstrated that isolates pathogenic on the genus Digitaria belong to a separate species (Couch and Kohn 2002). While the latter was termed Magnaporthe grisea, the isolates associated with Oryza sativa were named Magnaporthe oryzae (Couch and Kohn 2002).

One of our long-term goals is the improvement of resistance of barley against $M$. oryzae. This is an important task because the disease is becoming more prevalent (Lima and Minella 2003), and moreover, we determined that a major resistance trait of spring barley, namely, mlo resistance, conditions hypersusceptibility to blast (Jarosch et al. 1999). Here, we report an analysis of nonhost resistance of barley against $M$. grisea and a closely related, putative novel species associated with Pennisetum spp., and we discuss whether nonhost resistance could be exploited in a strategy to increase the resistance of barley against $M$. oryzae.

\section{RESULTS}

Infection assays.

Macroscopic disease rating using 15 Magnaporthe isolates originating from seven different host species in 11 countries was assessed on eight barley cultivars (Table 1). Accordingly, isolates could be grouped into two categories, the first of which consisted of Magnaporthe isolates that caused no disease on any of the barley genotypes tested and that had originated 
from Digitaria or Pennisetum spp. Infection assays with these isolates were performed on their native hosts to confirm that they had not lost pathogenicity during storage (data not shown). The second category consisted of Magnaporthe isolates from rice, maize, barley, Eleusine spp., and wheat that were pathogenic on almost all of the barley genotypes tested. Representative symptoms from inoculations of two barley genotypes with a representative Magnaporthe isolate from each category are depicted in Figure 1. Consistent with previously published results (Jarosch et al. 1999), the genotype IngridMlo was moderately susceptible, whereas the mlo genotype (BCIngridmlo5) was hypersusceptible to the TH $6772 \mathrm{M}$. oryzae isolate from rice (Fig. 1A). A correlation between the absence of the wildtype $M L O$ allele and a vigorous infection phenotype was ob- served among all barley mlo genotypes inoculated with virulent isolates of $M$. oryzae (data not shown). In contrast, no macroscopic influence of the $M L O$ or mlo allele was detected in interactions of any barley genotype with Magnaporthe isolates from Digitaria or Pennisetum spp., as exemplified by the IngridMlo and BCIngridmlo5, respectively, and CD 180 interactions (Fig. 1B).

\section{Cytology of the interaction.}

Next we investigated resistance at the cellular level. For comparability, we evaluated host and nonhost interactions in a single experiment. Microscopical investigations revealed that germination and appressoria formation of spores of both CD 180 and TH 6772 appeared normal. Applying bright-field and

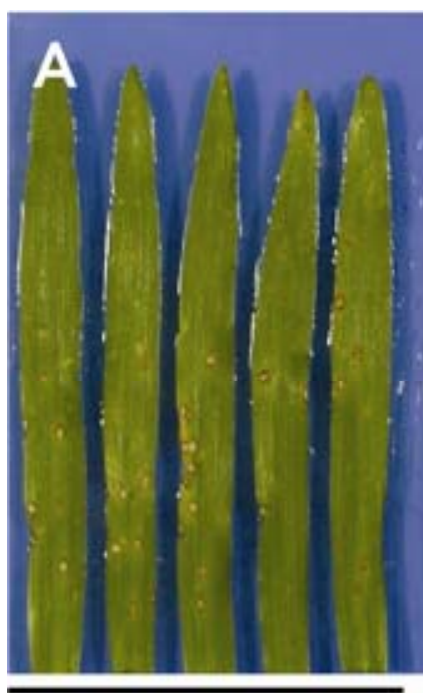

MIo

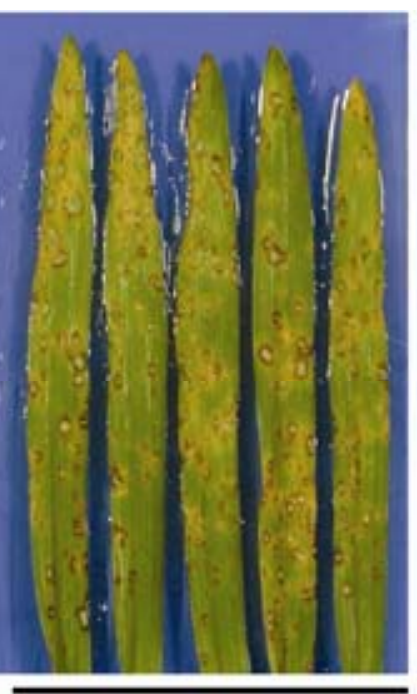

mlo-5

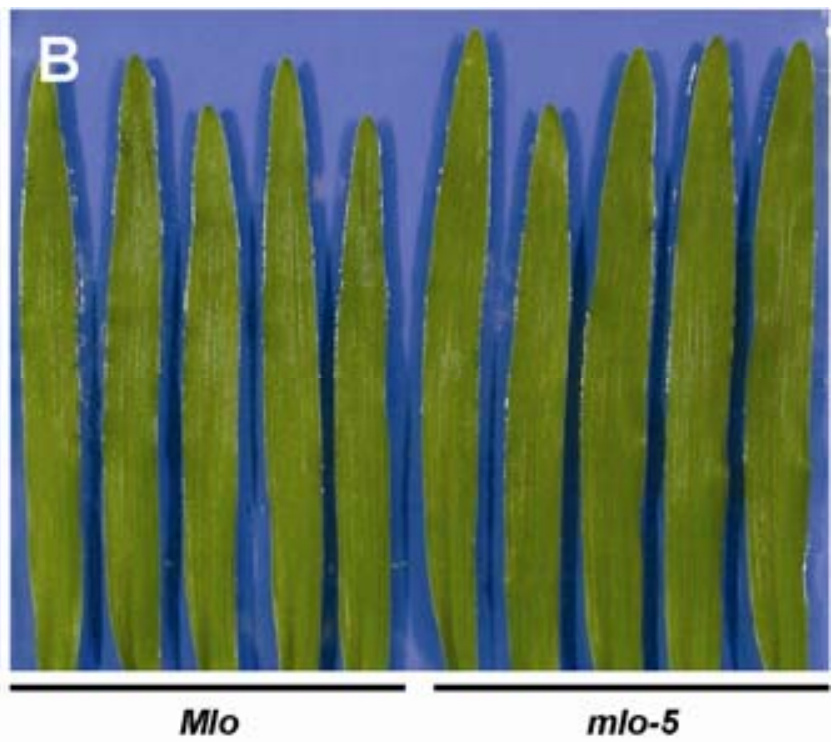

Fig. 1. Primary barley leaves infected with different Magnaporthe isolates. Infection phenotypes of barley cultivar Ingrid $M l o$ and the backcross line BCIngrid $m l o-$ 5 six days after inoculation with A, isolate TH 6772 from rice and B, isolate CD 180 from Pennisetum, respectively.

Table 1. Infection assays with Magnaporthe isolates derived from different hosts on eight different barley genotypes ${ }^{\mathrm{a}}$

\begin{tabular}{|c|c|c|c|c|c|c|c|c|c|c|}
\hline \multirow[b]{2}{*}{ Isolate } & \multirow[b]{2}{*}{ Host } & \multirow[b]{2}{*}{$\begin{array}{c}\text { Geographic } \\
\text { origin }\end{array}$} & \multicolumn{8}{|c|}{ Barley cultivar } \\
\hline & & & $\begin{array}{c}\text { Ingrid } \\
\text { Mlo }\end{array}$ & $\begin{array}{l}\text { BCIngrid } \\
\text { mlo-5 }\end{array}$ & Sultan5 & $\begin{array}{l}\text { Golden } \\
\text { Promise }\end{array}$ & Hannah & $\begin{array}{c}\text { Grannenlose } \\
\text { Zweizeilige } \\
\text { mlo-11 }\end{array}$ & $\begin{array}{c}\text { Malteria } \\
\text { Heda } m l o-3\end{array}$ & $\begin{array}{c}\text { BCPallas } \\
\text { mlo-5 }\end{array}$ \\
\hline \multirow[t]{2}{*}{ BR 29} & Digitaria & & & & & & & & & \\
\hline & sanguinalis & Brazil & - & - & - & - & - & - & - & - \\
\hline \multirow[t]{2}{*}{ IN 06} & Digitaria & & & & & & & & & \\
\hline & sanguinalis & India & - & - & - & - & - & - & - & - \\
\hline \multirow[t]{2}{*}{ JP 23} & Digitaria & & & & & & & & & \\
\hline & sanguinalis & Japan & - & - & - & - & - & - & - & - \\
\hline PH 55 & Digitaria ciliaris & Philippines & - & - & - & - & - & - & - & - \\
\hline \multirow[t]{2}{*}{ BF 17} & Pennisetum & & & & & & & & & \\
\hline & typhoides & Burkina Faso & - & - & - & - & - & - & - & - \\
\hline \multirow[t]{2}{*}{ CD 86} & Pennisetum & & & & & & & & & \\
\hline & typhoides & Ivory Coast & - & - & - & - & - & - & - & - \\
\hline CD 180 & Pennisetum sp. & Ivory Coast & - & - & - & - & - & - & - & - \\
\hline GN 01 & Maize & Gabon & + & + & + & + & / & l & + & / \\
\hline RW 12 & Eleusine coracana & Rwanda & + & + & + & + & + & + & + & + \\
\hline RW 18 & Eleusine coracana & Rwanda & + & + & + & + & + & + & + & + \\
\hline ТН 03 & Barley & Thailand & + & + & + & + & + & + & + & + \\
\hline BR 32 & Wheat & Brazil & + & + & + & + & + & + & + & + \\
\hline FR 13 & Rice & France & - & + & + & + & + & + & + & + \\
\hline PH 14 & Rice & Philippines & + & + & + & + & + & + & + & + \\
\hline PR 9 & Rice & Portugal & - & + & - & + & - & + & + & + \\
\hline SP 24 & Rice & Spain & - & + & + & + & + & + & + & + \\
\hline TH 6772 & Rice & Japan & + & + & + & + & + & + & + & + \\
\hline
\end{tabular}

${ }^{a}$ Barley cultivars were sprayed with spores of 17 Magnaporthe isolates as indicated. Disease severity was macroscopically evaluated 5 to 8 days after infection, and interactions showing disease symptoms (+) discriminated from those without disease symptoms (-). A shill (/) means that the interaction was not tested. Isolate name, host, and country of collection are as indicated. 
epi-fluorescence microscopy after inoculation of barley genotypes with CD 180 and TH 6772, respectively, we were able to distinguish four different cellular interaction phenotypes (Fig. 2 ). The first type referred to the apposition of cell-wall material at the site of initial penetration, i.e., papilla formation beneath the appressorium (Fig. 2A). The second type comprised autofluorescent cell walls of penetrated epidermal cells (Fig. 2B). The third and fourth types both were associated with autofluorescence of mesophyll tissue but differed in the integrity of cellular shape, i.e., cells were either globular or collapsed (Fig. 2C and D). The frequency of each cellular interaction phenotype was scored after inoculation of IngridMlo as well as BCIngridmlo5 at different timepoints (Fig. 3). Consistent with previously published results on the host-type interaction, a high frequency of effective papilla formation was associated with the moderate infection phenotype on the $M L O$ genotype in comparison with mlo genotypes (Jarosch et al. 1999, 2003, 2005). This situation was contrasted, for example, at $96 \mathrm{~h}$ after inoculation in the severely diseased mlo genotype in which a low frequency of papilla occurred together with a high frequency of a hypersensitive response (HR)-like cell death in the mesophyll. The affected mesophyll cells were collapsed. Formation of papillae was also found to be the predominant cellular response of barley attacked by CD 180 at 48 and $96 \mathrm{~h}$ after inoculation (Fig. 3). Significant quantitative differences were apparent between IngridMlo and BCIngridmlo5 genotypes, with approximately $70 \%$ of attempted epidermal cell penetrations responding with a papilla on IngridMlo and only 55 to $60 \%$ on BCIngridmlo5, respectively. These papillae could be considered as an effective defense, because hyphae were generally not observed growing beyond these appositions at the later timepoint. However, in cases in which ineffective papillae were breached and fungal hyphae grew on into epidermal cells, these accumulated fluorescent material in their cell walls. This autofluorescence was observed at $30 \%$ of the penetration sites on Ingrid Mlo and $40 \%$ on BCIngridmlo5 genotypes, respectively. Fluorescence in mesophyll cells occurred in both genotypes at less than $3 \%$ of the penetration sites. In these cases, and in contrast to the host interaction, mesophyll cells maintain their globular shape and autofluorescent material only accumulated in the cell walls. Collapsed mesophyll cells were detected at low incidence (less than 1\%). There were no substantial differences in the frequencies of interaction sites of samples harvested at 48 and $96 \mathrm{~h}$ after inoculation, respecttively, indicating that fungal colonization was not able to proceed. In summary, our microscopic investigations revealed that barley responded in the nonhost interaction with active defense responses.

\section{Quantification of fungal biomass in inoculated tissue.}

In order to quantify the degree of colonization of infected tissue and to rule out the possibility that a symptomless infection of barley by CD 180 might be occurring, we employed real-time quantitative polymerase chain reaction (PCR), using total DNA extracted from leaves $96 \mathrm{~h}$ after inoculation. $\mathrm{Ct}$ (cycle threshold) values were calculated, and the amount of fungal DNA was estimated using standard curves and was normalized to the amount of barley DNA in the sample. Fungal DNA was detected in all samples of inoculated leaves (Fig. 4). In accordance with the disease severity observed on infected leaves, the highest amount of fungal DNA was found in BCIngridmlo5 plants inoculated with TH 6772. Significantly lower concentrations (approximately sevenfold less) were present in Ingrid $M l o$ congruent with reduced disease symptoms on the leaves. The lowest amount of fungal DNA (approximately $0.2 \mathrm{pg}$ of fungal DNA per $10 \mathrm{ng}$ of barley DNA) was detected to an equal level in both barley genotypes inoculated with CD 180. These results suggest that fungal growth in the interaction of both barley genotypes with CD 180 is restricted at a very early stage of infection. Obviously, in the interaction of the isolate TH 6772 with IngridMlo, the fungus was able to accomplish further infection structures as indicated by the higher amount of fungal biomass.

\section{Phylogenetic analysis.}

On the basis of the evidence so far presented, it appears that barley inoculated with Magnaporthe isolates derived from Pennisetum or Digitaria spp. results in a nonhost type of interaction. Recently, an investigation of Digitaria-derived Magnaporthe isolates led to the recognition of two species in what
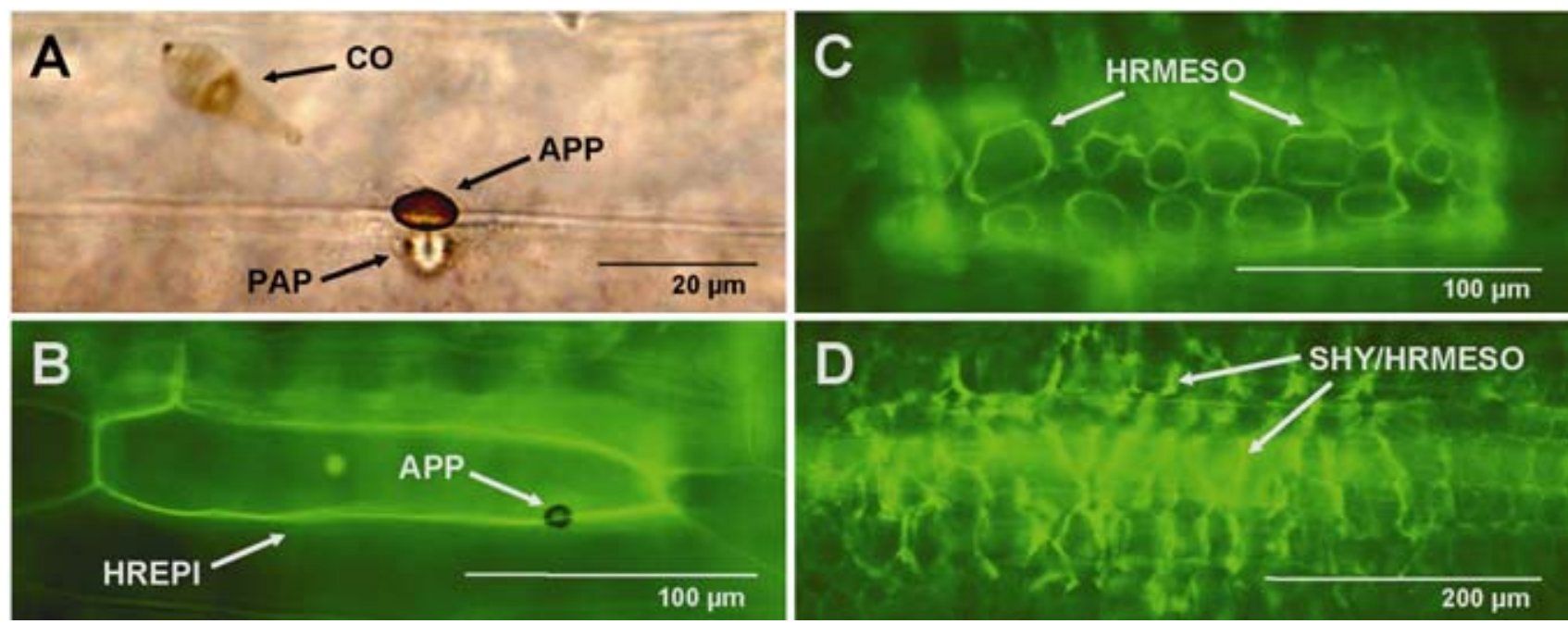

Fig. 2. Cellular interaction phenotypes of barley inoculated with either isolate TH 6772 from rice or CD 180 from Pennisetum spp. (96 h postinoculation). Four different types of cellular defense were discriminated as indicated. A, Bright-field microscopy was used to evaluate the formation of effective papilla formed beneath a fungal appressorium. Epi-fluorescence microscopy was used to detect autofluorescent material in $\mathbf{B}$, the epidermis and $\mathbf{C}$ and $\mathbf{D}$, the mesophyll. Pictures presented in A through C were taken from the nonhost interaction between IngridMlo and CD 180, while the interaction type depicted in D was chosen from the host type of interaction, i.e., BCIngridmlo-5 inoculated with TH 6772. Defense reactions in the mesophyll discriminated regular shaped cells $(\mathrm{C})$ vs. collapsed cells (D). APP = appressorium, $\mathrm{CO}=$ conidia, $\mathrm{PAP}=$ papilla, $\mathrm{HREPI}=$ epidermal hypersensitive response $(\mathrm{HR})$, $\mathrm{HRMESO}=\mathrm{HR}$ in mesophyll cells, and SHY/HRMESO = secondary hyphae together with HR-like cell death in mesophyll cells. 
was formerly accepted as M. grisea (Couch and Kohn 2002). We utilized the same rapid PCR-restriction fragment length polymorphism (RFLP)-based test published in that study to determine whether Pennisetum-derived isolates might cluster together with Digitaria isolates. Indeed, the absence of an HpaII restriction site, indicative of the $M$. grisea species, was confirmed for Digitaria isolates, and furthermore, we found the same pattern for the Pennisetum-derived isolates (Fig. 5). In contrast, intact restriction sites, i.e., the pattern associated with the species $M$. oryzae, were detected for all isolates that were able to infect barley.

To further clarify the phylogenetic relationship among the Magnaporthe isolates used in this study, we generated sequence information for fragments of three genes, actin, calmodulin, and $\beta$-tubulin. A partition homogeneity test performed in PAUP* showed that all three data sets were combinable $(P=$ 1.000), and therefore, they were analyzed as a combined data set comprising 17 Magnaporthe isolates and two outgroups (Fig. 6). The total length of the data set was 1,307 characters, 686 characters thereof were constant, 257 parsimony uninforma-

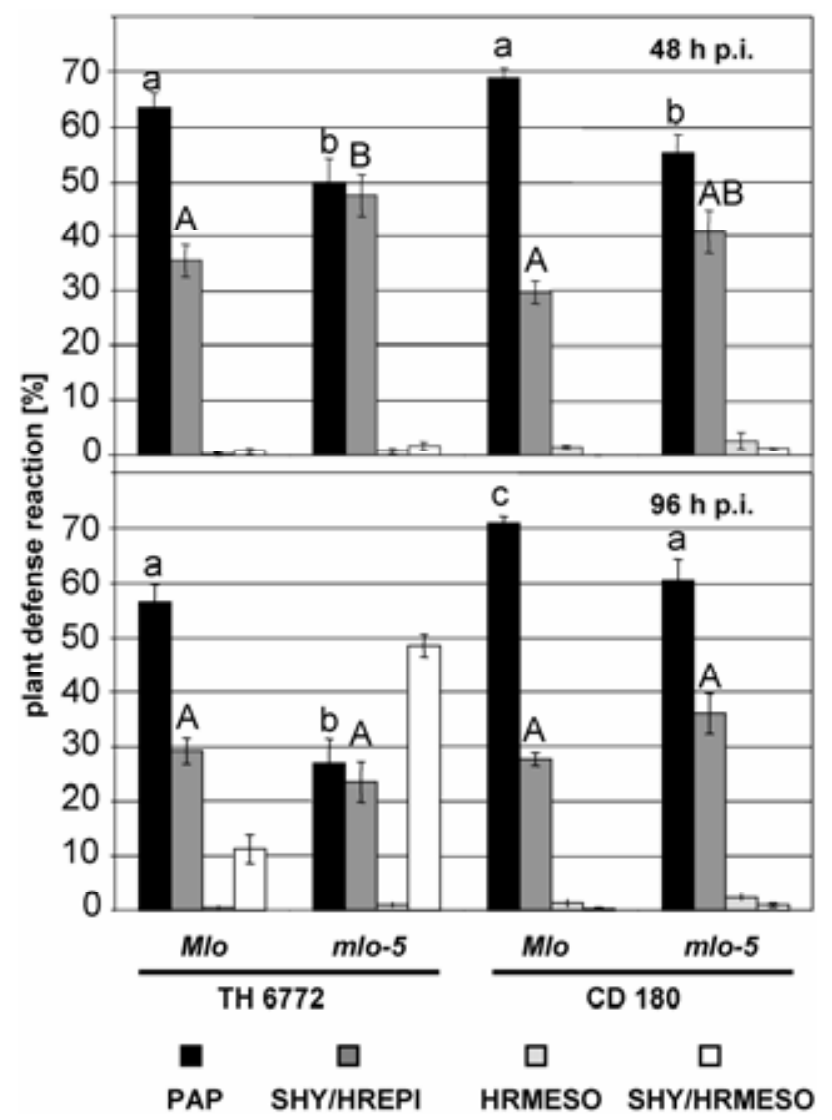

Fig. 3. Microscopic analysis of barley interacting with isolates TH 6772 from rice and CD 180 from Pennisetum spp., respectively. Primary leaves of barley cultivar IngridMlo and the backcross line Ingrid $m l o-5$ were inoculated with isolates TH 6772 from rice or CD 180 from Pennisetum spp. and were harvested 48 and $96 \mathrm{~h}$ after inoculation, respectively. Cellular plant-fungus interaction sites were classified according to the formation of effective papilla formed beneath a fungal appressorium or the detection of autofluorescent material in the epidermis and the mesophyll. Columns represent mean values and standard errors from four leaves with approx. 100 interaction sites inspected per genotype and per leaf. Significant differences (95\% confidence) between both genotypes were determined for papilla and epidermal hypersensitive response (HR), respectively, using the Student's $t$-test and are indicated by different roman letters. The experiment was repeated with similar results. $\mathrm{PAP}=$ effective papillae, $\mathrm{SHY} / \mathrm{HREPI}=$ secondary hyphae together with HR in epidermal cells, HRMESO $=\mathrm{HR}$ in regular shaped mesophyll cells, SHY/HRMESO = secondary hyphae together with HR-like cell death in mesophyll cells associated with cell collapse. tive and 364 parsimony informative. Parsimony analysis yielded six most parsimonious trees, and a representative tree is shown in Figure 6 ( TL $=893$ steps, $\mathrm{CI}=0.964, \mathrm{RI}=0.972, \mathrm{RC}=$ 0.937). Different, well-supported clades can be distinguished from this parsimony analysis. The first clade contains isolates from Digitaria spp. (100\% bootstrap support) that group with $100 \%$ bootstrap support with a clade consisting of isolates from Pennisetum spp. (100\% bootstrap support). Moreover, isolates from clades one and two were distinct from a third clade containing isolates from barley, wheat, rice, Eleusine spp., and maize (100\% bootstrap support).

Parsimony analyses using the sequence information of every gene singly (actin, calmodulin, and $\beta$-tubulin) result individually in the same general tree topology, as did all neighborjoining analyses using different substitution models (data not shown). Differences between the resulting trees only concern the internal order of taxa within clades one and three.

\section{DISCUSSION}

Rice blast, caused by the fungal pathogen Magnaporthe oryzae, is the most destructive disease occurring in rice plant cultivation world-wide (Rossmann et al. 1990). As rice is the major food crop for more than a third of the world's population, blast is considered one of the most important disease threats to world food supply (Xue et al. 2004). Breeding for resistance against blast has not met with lasting success, because resistance of newly developed cultivars was quickly overcome by a shift in the pathogen population to new virulent races (Hamer et al. 1993). Therefore, efforts have been made to define novel strategies to achieve durable resistance in rice against blast. One avenue under consideration is to employ the mechanisms of nonhost resistance. The present study can be viewed as a first step in this direction.

Barley has frequently been used as a host for Magnaporthe oryzae in studies searching for pathogenicity factors (Balhadère

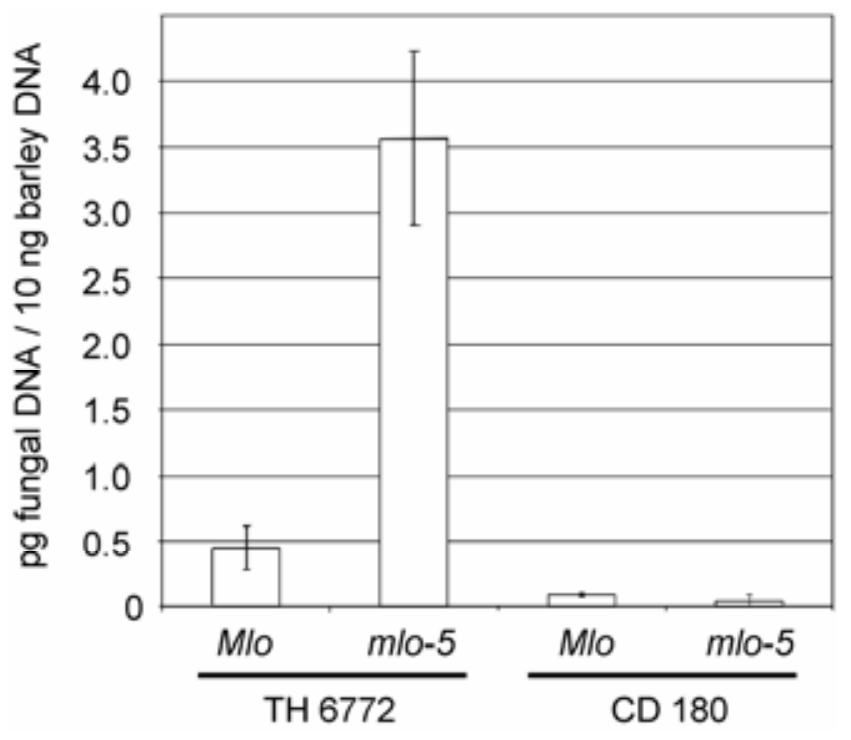

Fig. 4. Quantification of fungal DNA in barley leaves measured by real-time polymerase chain reaction (PCR). Seven-day-old barley seedlings (cultivar IngridMlo and backcross line BCIngridmlo-5) were inoculated with conidia of isolates CD 180 from Pennisetum spp. and TH 6772 from rice, respectively. Four days after inoculation, five leaves per interaction were harvested and pooled and total DNA was isolated. Real-time PCR analysis was performed to quantify the amount of fungal DNA. Concomitantly, barley DNA was measured in the same extracts and served as an internal standard. Each column represents the mean and standard error of three to four individual samples. The experiment was repeated twice with similar results. 
et al. 1999), because it has been thought of as a universal host for Magnaporthe isolates. In this study, we demonstrated that this assumption has to be revised. Using several Magnaporthe isolates originating from different host plants from the family Poaceae, we showed two distinct interaction categories with respect to the ability to infect barley. Strikingly, we observed that all isolates derived from the host genera Pennisetum or Digitaria were unable to cause disease on barley, whereas the other Magnaporthe isolates were pathogenic on barley. In all cases, infections on mlo genotypes appeared most devastating. This could be explained by the loss of a functional MLO protein that operates in basal resistance of barley against $M$. oryzae (Jarosch et al. 1999, 2005).

Although our survey comprised a limited number of barley genotypes and despite the fact that we can only speculate as to whether other barley genotypes would be similarly resistant, the available data clearly infer a nonhost type of interaction with isolates derived from Digitaria or Pennisetum species (Table 1). In general, nonhost resistance is defined at the species level, i.e., as the resistance expressed by a particular plant species against a pathogen from a different host species (Collinge and Slusarenko 1987; Heath 2001). Indeed, the genetic diversity and homogeneity observed among and between Magnaporthe isolates used in this study suggest that those isolates derived from Pennisetum spp. could be allocated to a new species, as was previously done with isolates from Digitaria spp. (Couch and Kohn 2002). Therefore, we will refer to isolates from Digitaria spp. as M. grisea, to isolates from Pennisetum spp. as a "putative novel species associated with Pennisetum," and to isolates from rice as $M$. oryzae. The other isolates pathogenic on barley that cluster together with $M$. oryzae are referred to as $M$. oryzae lineage. Our results are in accordance with an analysis of ITS sequences (P. Piffanelli, CIRAD, Montpellier, France personal communication) and a study performed at CIRAD (M.-H. Lebrun and J.-L. Notteghem, personal communication) that presumably will lead to a stable phylogenetic reorganization of the Magnaporthe species complex.

It seems that $M$. grisea and the putative novel species associated with Pennisetum spp., which appeared to be more closely related to each other than to the $M$. oryzae lineage, have not evolved pathogenicity on barley. Host species specificity in the blast fungus has been reported to be either multigenically or monogenically determined with respect to a given host (Sweigard et al. 1995; Zeigler 1998). In the latter case, fungal crosses were used to identify genes of interest, indicating that isolates used in these studies, which differ in their ability to infect particular host species, are interfertile and hence, by this biological criterion, belong to the same species (Murakami et al. 2000, 2003; Takabayashi et al. 2002). This is at variance with the situation described in the present study in that here the fungal isolates displaying different types of interaction towards barley are of greater phylogenetic divergence. This implies an evolutionarily earlier separation. Therefore, the question arises as to whether defense responses in barley against different Magnaporthe species might also vary.

At the cellular level, formation of effective papillae was found to be the predominant defense response against the nonhost isolate CD 180, which in turn, resembles the situation in the moderately susceptible host-type of interaction observed on $M L O$ genotypes (Jarosch et al. 1999, 2003, 2005). Similarly, successful penetration through ineffective papillae allowed the establishment of infection hyphae in epidermal cells and resulted in strong autofluorescence in the cell walls in both host and nonhost combinations. Epidermal cell autofluorescence is indicative of a HR (Koga et al. 1988). The timecourse study revealed that the infection by CD 180 did not proceed any further (Fig. 3), indicating that the HR in epidermal cells was effective in preventing accelerated tissue invasion. Similarly, pathogen restriction in the first penetrated epidermal cell was reported for incompatible rice- $M$. grisea interactions (Peng and Shishiyama 1988). This is an apparent difference from the barley host situation in which fungal mycelium was able to penetrate into the mesophyll. Thereafter, attacked mesophyll cells collapsed and underwent a HR-like cell death that was thought to allow development of the facultative biotroph fungus $M$. oryzae (Jarosch et al. 1999, 2003, 2005). This is strikingly similar to results obtained by Heath and associates (1990), who reported that, in highly compatible interactions of weeping lovegrass (Eragrostis) or rice with $M$. oryzae, fungal progression into the mesophyll is accompanied by cell collapse and autofluorescense. In contrast, autofluorescent mesophyll cells of the nonhost interaction reported in the present study kept their regular shape and were not invaded by the pathogen. Furthermore, strong autofluorescense of nonattacked mesophyll cells that are beneath epidermal cells that have stopped fungal invasion was reported for moderately susceptible interactions of $M$. oryzae with either weeping lovegrass or goosegrass (Heath et al. 1990). It is interesting that
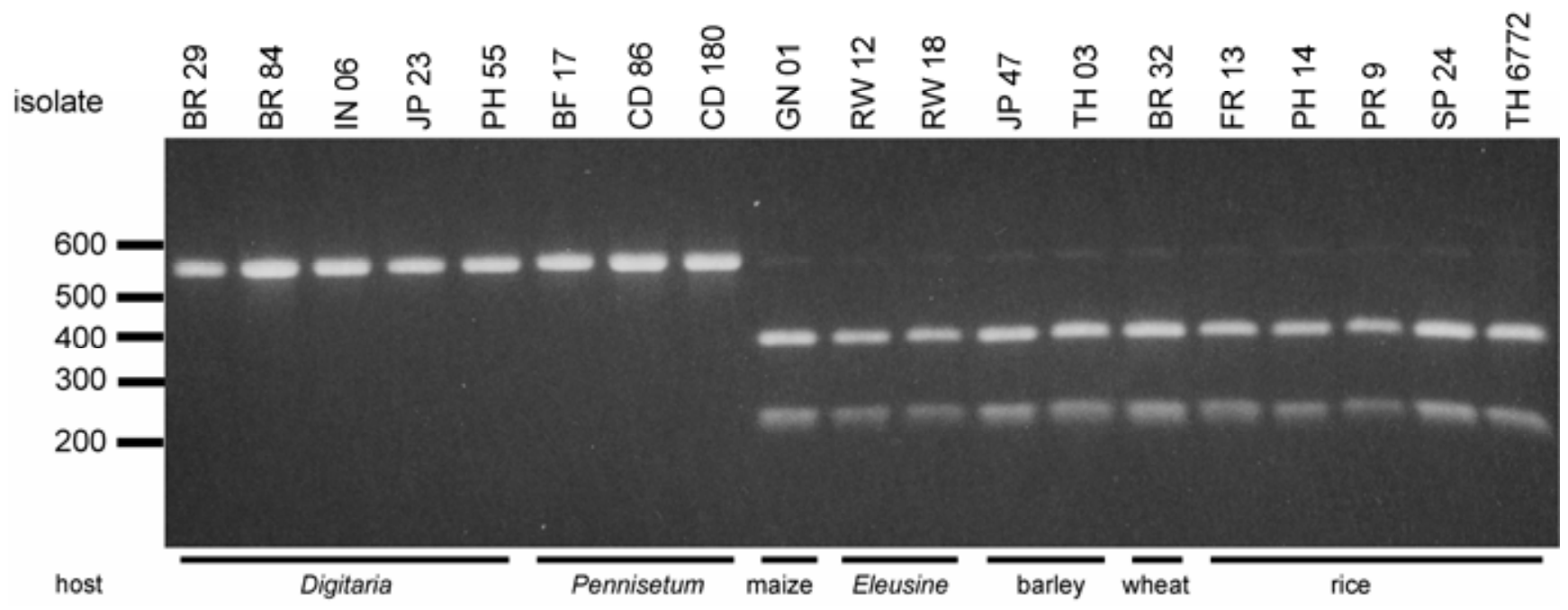

Fig. 5. Polymerase chain reaction (PCR)-restriction fragment length polymorphism of a Magnaporthe $\beta$-tubulin gene fragment. A gene fragment of the $\beta$-tubulin gene of 17 Magnaporthe isolates was PCR-amplified and digested with HpaII. Resulting DNA fragments were seperated by agarose gel electrophoresis and were visualized by ethidium bromide staining. Hosts for each Magnaporthe isolate are indicated by horizontal lines. 
this HR-like cell death occurs in cells that have no direct contact with the pathogen and might suggest that the contacted cells communicate the presence of the pathogen beyond their own boundary and set in motion an "anticipated" defense reaction against the pathogen in nearby cells. Accelerated defense mechanisms are also known from Arabidopsis mutants affected in the normal cell-death response (Greenberg et al. 1994).

Real-time PCR analysis further confirmed that, in the nonhost interaction, fungal colonization is halted at very low levels of fungal biomass (Fig. 4), indicating the effectiveness of cel-

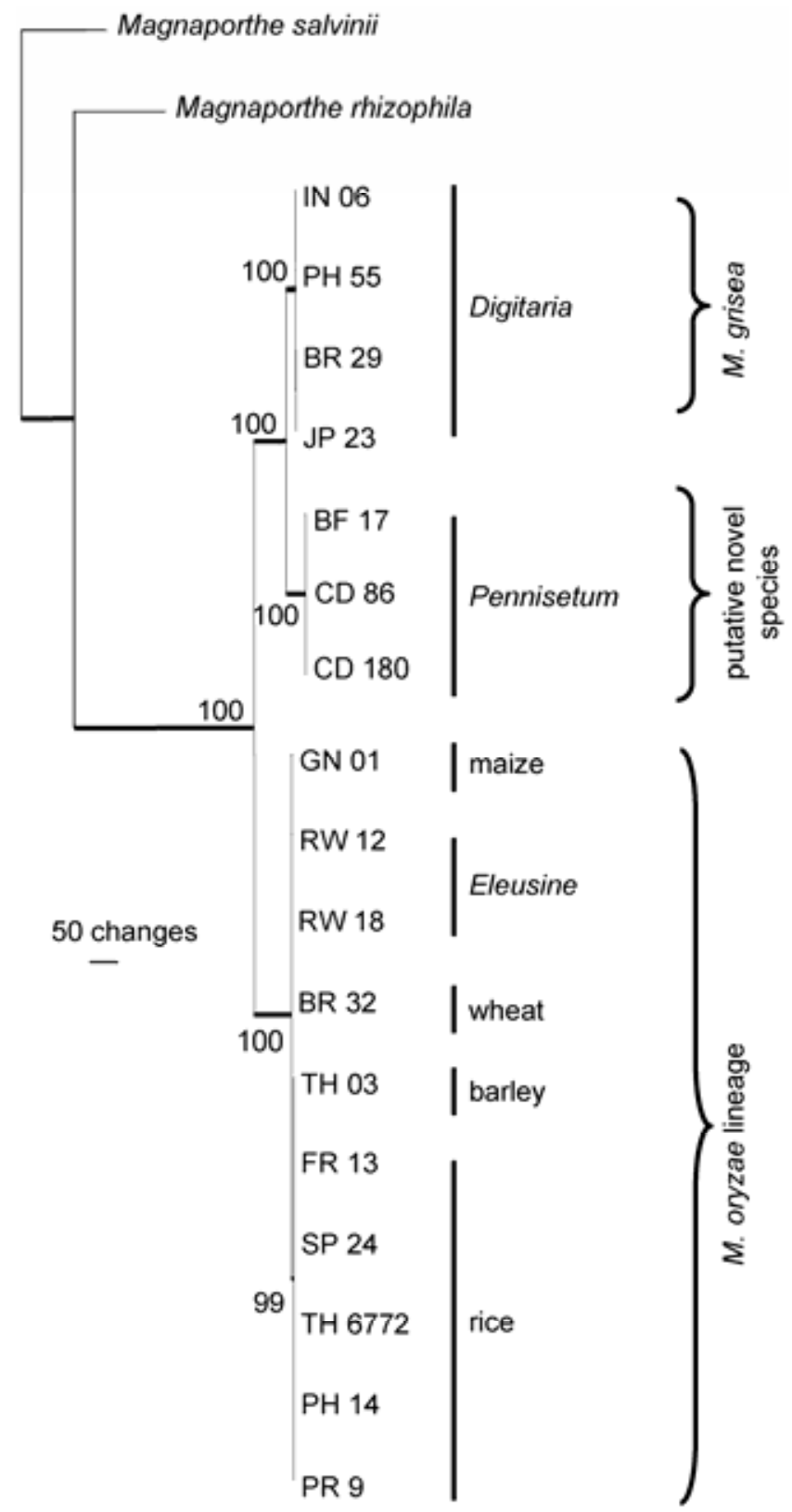

Fig. 6. One of six most parsimonious trees obtained from a combined analysis of the actin, calmodulin, and $\beta$-tubulin sequence alignment. Sequence information of actin, calmodulin, and $\beta$-tubulin gene fragments was used for parsimony analysis. One of six most parsimonious trees of the combined analysis of all three gene fragments is presented. Bootstrap support values based on 1,000 replicates are shown at nodes (scale bar represents 10 changes). Branches in the consensus tree are thickened. The tree was rooted to Magnaporthe salvinii (AF396030, AF395975, AF396004) and Magnaporthe rhizophila (AF396031, AF395972, AF396001). Phylogeny is labeled from left to right, isolate name, host from which the isolate was collected, and species into which isolates cluster. lular defense reactions. Furthermore, fungal growth was much less than in moderately susceptible host interactions with IngridMlo plants. Previous studies concerning the host interaction demonstrated that the loss of a functional MLO protein resulted in accelerated progression of hyphae into the mesophyll and was associated with enhanced disease severity (Jarosch et al. 1999, 2003, 2005). Likewise the MLO locus influences the nonhost interaction in a quantitative manner. Thus, mlo genotypes displayed a diminished papilla response, resulting in a higher frequency of HR in the epidermis (Fig. 3).

However, we have found no evidence for qualitative differences among the effective cellular defense responses of barley in host and nonhost interactions with different Magnaporthe species. This affirms the perception of similarity between the host and nonhost defense machinery made by Thordal-Christensen (2003). Taken together, it appears that, in the Magnaporthe nonhost situation, resistance is triggered faster and, hence, operates more efficiently. This, in turn, may be due to the "solidity" of a recognition event leading to resistance (Thordal-Christensen 2003). It could be speculated that so-called pathogen associated molecular patterns (PAMP) or general elicitors are involved in this process. PAMP are thought to trigger receptor-mediated defense responses in nonhost interactions (Nürnberger and Lipka 2005). In the course of evolution, nonhost resistance in a plant species seems to have been overcome by individual subpopulations of a given pathogen through the acquisition of virulence factors that enable them to evade or suppress plant resistance mechanisms (Nürnberger and Lipka 2005). Adapting this interpretation to the Magnaporthe system investigated in this study would mean that the putative species associated with Pennisetum spp. and M. grisea represent a more "ancestral" infection type that is recognized by barley through particular PAMP. In contrast, isolates of the $M$. oryzae lineage, which had overcome this barrier, had achieved virulence on barley and possibly on other grass varieties. Knowing the molecular players in this scenario will surely help to understand and perhaps, in the future, to modulate resistance of barley in plant protection programs. Further studies are required to test the hypotheses and tentative conclusions drawn in the present study.

\section{MATERIALS AND METHODS}

Fungal isolates and plant material.

The Magnaporthe isolates BR 29, BR 84, IN 06, JP 23, PH 55, BF 17, CD 180, CD 86, GN 01, RW 12, RW 18, JP 47, TH 03, BR 32, FR 13, PH 14, PR 9, and SP 24 were kindly provided by D. Tharreau (CIRAD, Montpelier, France). Isolate TH 6772 (031) was received from the Institute of Biochemistry, Facility of Agriculture, Tamagawa University, Machida-shi, Tokyo. All Magnaporthe isolates were grown on rice-leaf agar (water extract of $50 \mathrm{~g} \mathrm{l}^{-1}$ of rice leaves, $10 \mathrm{~g}$ of water soluble starch, $2 \mathrm{~g}$ $\mathrm{l}^{-1}$ of yeast extract [Biolabor, Bremen, Germany], $15 \mathrm{~g} \mathrm{l}^{-1}$ agaragar) and potato-dextrose agar (Becton, Dickinson and Company, Le Pont de Claix, France), respectively. They were cultivated at $27^{\circ} \mathrm{C}$ under blacklight (310 to $360 \mathrm{~nm}$ ) for two weeks under a 16-h day and 8-h night regime.

The spring barley (Hordeum vulgare L.) cultivars Ingrid, Sultan5, and Golden Promise and the mlo mutants Malteria Heda (mlo-3), Grannenlosen Zweizeilige (mlo-11), BCIngrid (mlo-5), and BCPallas (mlo-5) were provided by P. SchulzeLefert (Max-Planck Institute for Plant Breeding Research, Cologne, Germany). The winter barley cultivar Hannah was obtained from J. B. Speakman (BASF AG, Limburgerhof, Germany). Plants were grown in a growth chamber at $18^{\circ} \mathrm{C}$ with 50 to $60 \%$ relative humidity and a $16-\mathrm{h}$ photoperiod. 
Inoculation, infection assay, and microscopy.

Conidia were harvested from 2-week-old plates by rinsing with distilled water and filtering through three layers of gauze. The resulting suspension was diluted 1:1 ( $\mathrm{vol} / \mathrm{vol})$ with the spraying solution $(0.1 \%$ [wt/vol] gelatin, $0.05 \%$ [vol/vol] Tween 20), to give a final concentration of 200,000 conidia $\mathrm{ml}^{-1}$. Primary leaves of 7-day-old plants were spray-inoculated and incubated in a dark moist chamber at $26^{\circ} \mathrm{C}$ and $100 \%$ relative humidity. After $24 \mathrm{~h}$, the plants were returned to the growth chamber and were kept under the same temperature and light conditions described above.

For real-time PCR analysis, leaf samples of five primary leaves per sample were collected $96 \mathrm{~h}$ after inoculation, were immediately frozen in liquid nitrogen, and were stored at $-80^{\circ} \mathrm{C}$.

For macroscopic analysis, disease symptoms were evaluated 5 to 8 days after inoculation. Interactions were grouped into two classes, one of which comprised isolates that complete their life cycle and sporulate, and the other resembles those in which no disease symptoms (expanding diamond-shaped lesions $>3 \mathrm{~mm}$ in length with a grayish center) became visible.

Microscopy was performed as described by Jarosch and associates (2005).

\section{DNA extraction.}

Magnaporthe isolates were grown in $50 \mathrm{ml}$ of liquid Fries medium (Couch and Kohn 2002) and were incubated at $25^{\circ} \mathrm{C}$ for 4 to 6 days on a rotary shaker at $100 \mathrm{rpm}$. After filtration and lyophilization, mycelium was ground with liquid nitrogen and DNA was isolated, using the Nucleon PHYTOpure plant DNA extraction kit (Amersham Biosciences Europe $\mathrm{GmbH}$, Freiburg, Germany) following the manufacturer's instructions. Plant DNA from uninfected or infected leaves was isolated accordingly.

\section{DNA amplification and PCR-RFLP analysis.}

Fragments of the actin, calmodulin, and $\beta$-tubulin genes were amplified using the primer pairs ACT-512F and ACT783R, CAL-228F and CAL-737R (Carbone and Kohn 1999), and Bt1a and Bt1b (Glass and Donaldson 1995), respectively. PCR amplification was performed in a total volume of $12.5 \mu \mathrm{l}$ containing $2.5 \mathrm{pmol}$ of each primer, $1 \times$ PCR buffer, $\mathrm{MgCl}_{2}$ (actin, $2 \mathrm{mM}$; $\beta$-tubulin, $4.5 \mathrm{mM}$; and calmodulin, $2.5 \mathrm{mM}$ ), $20 \mu \mathrm{M}$ of each dNTP, and 0.25 units Taq polymerase (Bioline $\mathrm{GmbH}$, Luckenwalde, Germany). Fungal DNA was added to a

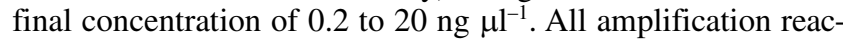
tions were performed on a GeneAmp PCR system 9600 (Perkin-

Table 2. Accession numbers for DNA sequence data of fungal actin, $\beta$ tubulin, and calmodulin genes deposited in GenBank

\begin{tabular}{lccc}
\hline & \multicolumn{3}{c}{ GenBank accession } \\
\cline { 2 - 4 } Isolate & Actin & $\boldsymbol{\beta}$-tubulin & Calmodulin \\
\hline BR 29 & DQ240874 & DQ240906 & DQ240890 \\
IN 06 & DQ240875 & DQ240907 & DQ240891 \\
JP 23 & DQ240876 & DQ240908 & DQ240892 \\
PH 55 & DQ240877 & DQ240909 & DQ240893 \\
BF 17 & DQ240878 & DQ240910 & DQ240894 \\
CD 86 & DQ240879 & DQ240911 & DQ240895 \\
CD 180 & DQ240880 & DQ240912 & DQ240896 \\
RW 18 & DQ240881 & DQ240913 & DQ240897 \\
GN 01 & DQ240882 & DQ240914 & DQ240898 \\
TH 03 & DQ240883 & DQ240915 & DQ240899 \\
BR 32 & DQ240884 & DQ240916 & DQ240900 \\
FR 13 & DQ240885 & DQ240917 & DQ240901 \\
SP 24 & DQ240886 & DQ240918 & DQ240902 \\
TH 6772 & DQ240887 & DQ240919 & DQ240903 \\
PH 14 & DQ240888 & DQ240920 & DQ240904 \\
PR 9 & DQ240889 & DQ240921 & DQ240905 \\
\hline
\end{tabular}

Elmer, Norwalk, CT, U.S.A.), using thermal cycling conditions for all primer pairs, which consisted of $5 \mathrm{~min}$ at $95^{\circ} \mathrm{C}$, followed by 40 cycles of $30 \mathrm{~s}$ at $95^{\circ} \mathrm{C}, 30 \mathrm{~s}$ at $52^{\circ} \mathrm{C}$, and $1 \mathrm{~min}$ at $72^{\circ} \mathrm{C}$. The final extension was $10 \mathrm{~min}$ at $72^{\circ} \mathrm{C}$. PCR products were separated by gel electrophoresis using a $0.8 \%$ (wt/vol) agarose gel containing ethidium bromide and were visualized under UV light.

For PCR-RFLP analysis, the $\beta$-tubulin amplification product was digested with HpaII (Fermentas GMBH, St. Leon-Rot, Germany), after electrophoresis and gel eluation (QIAquick gel extraction kit, Qiagen GmbH, Hilden, Germany). Restriction fragments were visualized on a $1.5 \%(\mathrm{wt} / \mathrm{vol})$ agarose gel.

\section{Sequencing and phylogenetic analyses.}

The forward and reverse strands of the amplification products were sequenced, using the same primers as in the amplification reactions. Sequence reactions were performed with an ABI Prism Big Dye Terminator v3.1 cycle sequencing ready reaction kit (PE Biosystems, Foster City, CA, U.S.A.) containing AmpliTaq DNA polymerase, following the manufacturer's instructions. The PCR conditions for sequencing consisted of 1 min at $95^{\circ} \mathrm{C}$, followed by 30 cycles of $10 \mathrm{~s}$ at $95^{\circ} \mathrm{C}, 5 \mathrm{~s}$ at $50^{\circ} \mathrm{C}$, and $4 \mathrm{~min}$ at $60^{\circ} \mathrm{C}$. All sequencing reactions were performed on an ABI Prism 3700 DNA Sequencer (Perkin-Elmer, Foster City, CA, U.S.A.). Electropherograms were analyzed using the sequence analysis software 4Peaks v1.6 (by A. Griekspoor and T. Groothuis, The Netherlands Cancer Institute, Amsterdam), were exported into the FASTA format and aligned with Sequence Alignment Editor v2.0a11 (Department of Zoology, Oxford University), and finally, were exported in NEXUS format.

All phylogenetic analyses were done with PAUP v4.0b10 (phylogenetic analysis using parsimony; Swofford 2002). Sequences of Magnaporthe salvinii (GenBank accession numbers AF396030, AF395975, and AF396004) and Magnaporthe rhizophila (GenBank accession numbers, AF396031, AF395972, and AF396001) were used as paraphyletic outgroups, and the sequence data of the actin, calmodulin, and $\beta$ tubulin genes were analyzed individually. To test if data of all genes can be used in a combined analysis, a partition homogeneity test (Farris et al. 1994) was performed in PAUP. For all maximum parsimony analyses, heuristic searches were conducted using the stepwise addition option with 100 random taxa additions. Alignment gaps were treated as a fifth character, and all characters were unordered and of equal weight. Tree bisection-reconnection was used as branch-swapping algorithm. Tree length, consistency index, retention index, and rescaled consistency index (TL, CI, RI, and RC, respectively) values were calculated. The robustness of the parsimonious trees was evaluated by 1,000 bootstrap replications (Hillis and Bull 1993).

Additionally, neighbor-joining analyses were conducted using the uncorrected $(p)$, Jukes-Cantor, Kimura 2-parameter, and HKY85 substitution models. Gaps were treated as missing data, characters were unordered and of equal weight, and ties were broken randomly when encountered.

All trees were printed with TreeView v1.6.6 (Page 1996). Sequences were deposited in GenBank (accession numbers are listed in Table 2) and the alignments and tree in TreeBASE (accession number SN2520).

\section{Real-time PCR.}

For the detection of Magnaporthe DNA, primers based on the $3^{\prime}$ end of the 28S rDNA gene as reported by Qi and Yang (2002) were used. A plant-specific primer pair (GIGf: 5'-AGC TTT GCC AGG GGG CAG CAA AAG ACC AAC-3', GIGr: 5'-GCT CAC AAG ATA AGG CAC AAA CAG CAG CCA 
GCA C-3') was designed to measure the amount of barley DNA in each sample. These primers were specific for the barley single-copy flowering time-regulator gene GIGANTEA (GenBank, accession number AF411229).

Real-time PCR was performed on an ABI 7000 sequence detection system (Applied Biosystems, Foster City, CA, U.S.A.) using Thermo-Fast 96 detection plates (ABgene, Epsom, Surrey, U.K.) and the ABI PRISM optical adhesive cover starter kit (Perkin-Elmer). The amplification reactions were performed with a qPCR core kit for SYBRGreen I (Eurogentec, Seraing, Belgium) in $20 \mu \mathrm{l}$ containing 5 pmol of each primer and $0.2 \mathrm{mM}$ dNTPs in PCR buffer with $6 \mathrm{mM} \mathrm{MgCl}_{2}$ (for fungus-specific primers) or $2.5 \mathrm{mM} \mathrm{MgCl}_{2}$ (for barleyspecific primers) and 0.5 units of Hot Gold Star enzyme (Eurogentec), SYBR green following the manufacturer's instructions, and $5 \mu \mathrm{l}$ of a diluted DNA solution. Standard curves were constructed using a series of known dilutions of Magnaporthe and barley DNA, respectively, to serve as reference to calculate the unknown fungus and plant DNA amounts in the samples. The fungus standard curve was established using $0.5 \mathrm{pg}, 5 \mathrm{pg}, 50 \mathrm{pg}, 500 \mathrm{pg}$, and 5,000 pg of fungal DNA mixed in a background of $25 \mathrm{ng}$ barley DNA from uninfected leaves. A linear relationship between the concentration of fungal DNA and the corresponding Ct values was found. Approximately 3.5 cycle differences represent a 10 -fold dilution difference between two samples; moreover the correlation coefficient of the fungal standard curve averaged 0.99 (results of at least three experiments). The barley standard curve was constructed using serial dilutions of barley DNA in a bovine serum albumin (BSA) background (100 $\mathrm{ng}^{-1} \mathrm{l}^{-1}$ ). DNA concentrations of $5 \times 10^{4} \mathrm{pg}, 1 \times 10^{4} \mathrm{pg}, 2 \times 10^{3} \mathrm{pg}$, and $4 \times 10^{2} \mathrm{pg}$ cause an average cycle difference of 2.8 cycles between the dilutions. The correlation coefficient of the barley standard curve was at least 0.99 (results of at least three experiments). Nontemplate controls show a $\mathrm{Ct}$ value larger than 35 for both fungal and barley primer pairs.

The amount of fungal and barley DNA in infected barley leaves was measured in the linear range of the standard curves. To prevent DNA absorption by the reaction tube wall, dilutions were made in BSA solution $\left(100 \mathrm{ng} \mathrm{ll}^{-1}\right)$ instead of water. Thermal cycling conditions used for both primer pairs consisted of $10 \mathrm{~min}$ at $95^{\circ} \mathrm{C}$, followed by 40 cycles of $30 \mathrm{~s}$ at $95^{\circ} \mathrm{C}, 1 \mathrm{~min}$ at $60^{\circ} \mathrm{C}$, and $1 \mathrm{~min}$ at $72^{\circ} \mathrm{C}$. Standard curves and DNA amounts were calculated by the ABI PRISM 7000 SDS software v1.0 (Applied Biosystems).

\section{ACKNOWLEDGMENTS}

We are grateful to D. Tharreau for providing most of the Magnaporthe isolates used in this study. Moreover, we are deeply grateful to him for continuous discussions and helpful suggestions during the course of this study. We thank A. J. Slusarenko for helpful discussions during the preparation of the manuscript. N. Zellerhoff was supported by a grant from the Rheinisch-Westfälische Technische Hoschschule Aachen University, her research stay at the Centraalbureau foor Schimmelcultures was funded by a framework program VI European-funded Integrated Infrastructure Initiative grant, called SYNTHESYS, application reference NL-TAF-748.

\section{LITERATURE CITED}

Balhadère, P. V., Foster, A. J., and Talbot, N. J. 1999. Identification of pathogenicity mutants of the rice blast fungus Magnaporthe grisea by insertional mutagenesis. Mol. Plant-Microbe Interact. 12:129-142.

Carbone, I., and Kohn, L. M. 1999. A method for designing primer sets for speciation studies in filamentous ascomycetes. Mycologia 91:553-556.

Collinge, D. B., and Slusarenko, A. J. 1987. Plant gene-expression in response to pathogens. Plant Mol. Biol. 9:389-410.

Couch, B. C., Fudal, I., Lebrun, M. H., Tharreau, D., Valent, B., van Kim, P., Notteghem, J. L., and Kohn, L. M. 2005. Origins of host-specific populations of the blast pathogen Magnaporthe oryzae in crop domesti- cation with subsequent expansion of pandemic clones on rice and weeds of rice. Genetics 170:613-630.

Couch, B. C., and Kohn, L. M. 2002. A multilocus gene genealogy concordant with host preference indicates segregation of a new species, Magnaporthe oryzae, from M. grisea. Mycologia 94:683-693.

Farris, J. S., Kallersjo, M., Kluge, A. G., and Bult, C. 1994. Testing significance of incongruence. Cladistics 10:315-319.

Glass, N. L., and Donaldson, G. C. 1995. Development of primer sets designed for use with the PCR to amplify conserved genes from filamentous ascomycetes. Appl. Environ. Microb. 61:1323-1330.

Greenberg, J. T., Guo, A. L., Klessig, D. F., and Ausubel, F. M. 1994. Programmed cell death in plants: A pathogen-triggered response activated coordinately with multiple defense Functions. Cell 77:551-563.

Hamer, J. E., Talbot, N. J., and Levy, M. 1993. Genome dynamics and pathotype evolution in the rice blast fungus. Pages 299-311 in: Advances in Molecular Genetics Of Plant-Fungus Interactions. E. W. Nester and D. P. S. Venna, eds. Kluwer Academic, Dordrecht, The Netherlands.

Heath, M. C. 2000. Nonhost resistance and nonspecific plant defenses. Curr. Opin. Plant Biol. 3:315-319.

Heath, M. C. 2001. Non-host resistance to plant pathogens: Nonspecific defense or the result of specific recognition events? Physiol. Mol. Plant Pathol. 58:53-54.

Heath, M. C., Valent, B., Howard, R. J., and Chumley, F. G. 1990. Interactions of two strains of Magnaporthe grisea with rice, goosegrass and weeping lovegrass. Can. J. Bot. 68:1627-1637.

Hillis, D. M., and Bull, J. J. 1993. An empirical-test of bootstrapping as a method for assessing confidence in phylogenetic analysis. Syst. Biol. 42:182-192.

Holub, E. B., and Cooper, A. 2004. Matrix, reinvention in plants: How genetics is unveiling secrets of non-host disease resistance. Trends Plant Sci. 9:211-214

Jarosch, B., Collins, N. C., Zellerhoff, N., and Schaffrath, U. 2005. RAR1, $R O R 1$, and the actin cytoskeleton contribute to basal resistance to Magnaporthe grisea in barley. Mol. Plant-Microbe Interact. 18:397-404.

Jarosch, B., Jansen, M., and Schaffrath, U. 2003. Acquired resistance functions in mlo barley, which is hypersusceptible to Magnaporthe grisea. Mol. Plant-Microbe Interact. 16:107-114.

Jarosch, B., Kogel, K. H., and Schaffrath, U. 1999. The ambivalence of the barley Mlo locus: Mutations conferring resistance against powdery mildew (Blumeria graminis f. sp. hordei) enhance susceptibility to the rice blast fungus Magnaporthe grisea. Mol. Plant-Microbe Interact. 12:508514.

Koga, H., Zeyen, R. J., Bushnell, W. R., and Ahlstrand, G. G. 1988. Hypersensitive cell death, autofluorescence, and insoluble silicon accumulation in barley leaf epidermal cells under attack by Erysiphe graminis f. sp. hordei. Physiol. Mol. Plant Pathol. 32:395-409.

Lima, M. I. P. M., and Minella, E. 2003. Occurrence of head blast in barley. Fitopatologia Brasileira 28:207.

Matsumura, K., and Tosa, Y. 1995. The rye mildew fungus carries avirulence genes corresponding to wheat genes for resistance to races of the wheat mildew fungus. Phytopathology 85:753-756.

Murakami, J., Tomita, R., Kataoka, T., Nakayashiki, H., Tosa, Y., and Mayama, S. 2003. Analysis of host species specificity of Magnaporthe grisea toward foxtail millet using a genetic cross between isolates from wheat and foxtail millet. Phytopathology 93:42-45.

Murakami, J., Tosa, Y., Kataoka, T., Tomita, R., Kawasaki, J., Chuma, I., Sesumi, Y., Kusaba, M., Nakayashiki, H., and Mayama, S. 2000. Analysis of host species specificity of Magnaporthe grisea toward wheat using a genetic cross between isolates from wheat and foxtail millet. Phytopathology 90:1060-1067.

Mysore, K. S., and Ryu, C. M. 2004. Nonhost resistance: How much do we know? Trends Plant Sci. 9:97-104.

Nürnberger, T., and Lipka, V. 2005. Non-host resistance in plants: New insights into an old phenomenon. Mol. Plant Pathol. 6:335-345.

Peng, Y. L., and Shishiyama, J. 1988. Temporal sequence of cytological events in rice leaves infected with Pyricularia oryzae. Can. J. Bot. 66:730-735.

Qi, M., and Yang, Y. N. 2002. Quantification of Magnaporthe grisea during infection of rice plants using real-time polymerase chain reaction and northern blot/phosphoimaging analyses. Phytopathology 92:870876.

Rossmann, A. Y., Howard, R. J., and Valen, B. 1990. Pyricularia grisea, the correct name for the rice blast disease fungus. Mycologica 82:509512.

Sweigard, J. A., Carroll, A. M., Kang, S., Farrall, L., Chumley, F. G., and Valent, B. 1995. Identification, cloning, and characterization of PWL2, a gene for host species specificity in the rice blast fungus. Plant Cell $7: 1221-1233$

Swofford, D. 2002. PAUP 4.0b10: Phylogenetic analysis using parsimony, Sunderland, MA, U.S.A. 
Takabayashi, N., Tosa, Y., Oh, H. S., and Mayama, S. 2002. A gene-forgene relationship underlying the species-specific parasitism of Avena/Triticum isolates of Magnaporthe grisea on wheat cultivars. Phytopathology 92:1182-1188.

Thordal-Christensen, H. 2003. Fresh insights into processes of nonhost resistance. Curr. Opin. Plant Biol. 6:351-357.

Xue, C., Li, L., Seong, K., and Xu, J.-R. 2004. Fungal pathogenesis in the rice blast fungus Magnaporthe grisea. Pages 138-165 in: Plant-Pathogen
Interactions, Vol. 11. N. J. Talbot, ed. Blackwell Publishing Ltd., Oxford. Zeigler, R. S. 1998. Recombination in Magnaporthe grisea. Annu. Rev. Phytopathol. 36:249-275.

\section{AUTHOR-RECOMMENDED INTERNET RESOURCE}

4Peaks v1.6 software: www.mekentosj.com 